\title{
Original Article \\ KIOM-4 Protects against oxidative Stress-Induced Mitochondrial Damage in Pancreatic $\beta$-cells via its Antioxidant Effects
}

\author{
Kyoung Ah Kang,, Jin Sook Kim, ${ }^{2}$ Rui Zhang, ${ }^{1}$ Mei Jing Piao, ${ }^{1}$ Young Hee Maeng, ${ }^{1}$ \\ Mi Young Kang, ${ }^{3}$ In Kyung Lee, ${ }^{4}$ Bum Joon Kim, ${ }^{4}$ and Jin Won Hyun ${ }^{1}$ \\ ${ }^{1}$ School of Medicine, Jeju National University, Jeju-si 690-756, Republic of Korea \\ ${ }^{2}$ Diabetic Complication Research Center, Division of Traditional Korean Medicine Integrated Research, \\ Korea Institute of Oriental Medicine, Daejeon, Republic of Korea \\ ${ }^{3}$ Department of Biomaterials, DNA Repair Center, Chosun University, Gwangju, Republic of Korea \\ ${ }^{4}$ Department of Microbiology and Caner Research Institute, Seoul National University College of Medicine, Seoul, Republic of Korea \\ Correspondence should be addressed to Jin Won Hyun, jinwonh@jejunu.ac.kr
}

Received 22 October 2009; Accepted 29 December 2009

Copyright (C) 2011 Kyoung Ah Kang et al. This is an open access article distributed under the Creative Commons Attribution License, which permits unrestricted use, distribution, and reproduction in any medium, provided the original work is properly cited.

\begin{abstract}
The protective effect of KIOM-4, a mixture of plant extracts, was examined against streptozotocin (STZ)-induced mitochondrial oxidative stress in rat pancreatic $\beta$-cells (RINm5F). KIOM-4 scavenged superoxide and hydroxyl radicals generated by xanthine/xanthine oxidase and Fenton reaction $\left(\mathrm{FeSO}_{4} / \mathrm{H}_{2} \mathrm{O}_{2}\right)$, respectively, in a cell-free chemical system. In addition, a marked increase in mitochondrial reactive oxygen species (ROS) was observed in STZ-induced diabetic cells; this increase was attenuated by KIOM-4 treatment. Mitochondrial manganese superoxide dismutase (Mn SOD) activity and protein expression were downregulated by STZ treatment and up-regulated by KIOM-4 treatment. In addition, NF-E2 related factor 2 (Nrf2), a transcription factor for Mn SOD, was up-regulated by KIOM-4. KIOM-4 prevented STZ-induced mitochondrial lipid peroxidation, protein carbonyl and DNA modification. Moreover, KIOM-4 treatment restored the loss of mitochondrial membrane potential $(\Delta \psi)$ that was induced by STZ treatment, and inhibited the translocation of cytochrome c from the mitochondria to the cytosol. In addition, KIOM-4 treatment elevated the level of ATP, succinate dehydrogenase activity and insulin level, which were reduced by STZ treatment. These results suggest that KIOM-4 exhibits a protective effect through its antioxidant effect and the attenuation of mitochondrial dysfunction in STZ-induced diabetic cells.
\end{abstract}

\section{Introduction}

Mitochondria have gained importance in our understanding of diabetes because mitochondrial function is required for normal glucose-stimulated insulin release from pancreatic $\beta$-cells [1]. Mitochondria continuously generate superoxide radical as a byproduct of electron transport $[2,3]$. The superoxide anion is quickly dismutated to hydrogen peroxide by mitochondrial manganese superoxide dismutase (Mn SOD) [4], and hydrogen peroxide is subsequently converted to water and oxygen by mitochondrial catalase and glutathione peroxidase [5]. Mitochondria not only produce reactive oxygen species (ROS) but are also the primary target of ROS attacks. Impaired mitochondrial function can lead to increased ROS generation and may increase oxidative stress if the antioxidant defense mechanisms of the cells are overwhelmed $[6,7]$. Increased oxidative stress by mitochondrial dysfunction is considered a causal link between elevated glucose and the major biochemical pathways postulated to be involved in the pathogenesis of diabetes and diabetic complications $[8,9]$. Streptozotocin (STZ) [ $N$-(methyl nitro carbamoyl)-D-glucosamine] has been used to act as diabetogenic agent due to its ability to destruct pancreatic $\beta$-cells via the formation of ROS $[10,11]$. It has been reported that production of mitochondrial ROS increased in STZ-treated rat, and mitochondrial lipid peroxidation was observed in pancreatic tissue, suggesting STZ-induced mitochondrial oxidative stress [12]. Thus, antioxidant therapy may be a promising therapeutic approach for controlling diabetes or diabetic complications. 
KIOM-4 is a combination of extracts obtained from Magnolia officinalis, Pueraria lobata, Glycyrrhiza uralensis and Euphorbia pekinensis. M. officinalis exhibits antimutagenic, hepato-protective, neuro-protective, antiinflammatory and antimicrobial activities [13-18]. P. lobata has antimutagenic, antidiabetic and antioxidant effects [1921]. G. uralensis has been documented as having detoxification, antioxidant, antiulcer, antiinflammatory, antiviral, antiatherogenic, anticarcinogenic effects and cytoprotective effect of hepatocyte against hepatotoxicity [22-24]. E. pekinensis has antiviral and cytotoxic activities $[25,26]$. We recently demonstrated that KIOM-4 exhibits cytoprotective effects against STZ-induced oxidative stress damage in $\beta$-cells via the activation of catalase and heme oxygenase-1 $[27,28]$.

This study was undertaken to investigate the protective effect of KIOM-4 and its mechanism against STZ-induced oxidative mitochondrial damage in pancreatic $\beta$-cells.

\section{Methods}

2.1. Preparation of KIOM-4. The cortex of M. officinalis, and radixes of P. lobata, G. uralensis and E. pekinensis were collected from the Gamsuk province in China, and identified by Prof. J.H. Kim of the Division of Life Science, Daejeon University, Korea. All voucher specimens were deposited at the herbarium of the Department of Herbal Pharmaceutical Development, Korea Institute of Oriental Medicine (No. 1240, 2, 7 and 207, resp.). An equal amount of Magnoliae cortex, and radixes of Puerariae, Glycyrrhizae and Euphoriae was mixed, pulverized and extracted in $80 \%$ ethanol for one week at room temperature, concentrated using a rotary evaporator and lyophilized. The entire procedure was repeated four times. KIOM-4 was dissolved in dimethyl sulfoxide (DMSO), the final concentration of which did not exceed $0.1 \%$.

2.2. Reagents. STZ was purchased from Calbiochem (San Diego, CA). Dihydrorhodamin 123 (DHR 123) and JC-1 (5,5',6,6' -tetrachloro-1,1' ,3, $3^{\prime}$-tetraethyl-benzimidazolcarbocyanine iodide) were purchased from Molecular Probes (Eugene, OR). Cytochrome $c$ (H-104), Nrf2 (C-20) antibodies were purchased from the Santa Cruz Biotechnology (Santa Cruz, CA). The Mn SOD polyclonal antibody was purchased from the Stressgen Corporation (Victoria, Canada). 5, 5-dimethyl-1-pyrroline-N-oxide (DMPO) and [3-(4,5-dimethylthiazol-2-yl)-2,5-diphenyltetrazolium] bromide (MTT) were purchased from the Sigma Chemical Company (St. Louis, MO).

2.3. Cell Culture and Treatments. RINm5F rat pancreatic $\beta$ cells were maintained at $37^{\circ} \mathrm{C}$ in an incubator with a humidified atmosphere of $5 \% \mathrm{CO}_{2}$, and cultured in RPMI- 1640 medium containing $10 \%$ heat-inactivated fetal calf serum, streptomycin $\left(100 \mu \mathrm{g} \mathrm{ml}^{-1}\right)$ and penicillin (100 units $\left.\mathrm{ml}^{-1}\right)$. Cells were seeded on to a culture plate at a concentration of $1 \times 10^{5}$ cells $\mathrm{ml}^{-1}$, and at $16 \mathrm{~h}$ after plating were treated with KIOM-4 at $50 \mu \mathrm{g} \mathrm{ml}^{-1}$. After $1 \mathrm{~h}, 10 \mathrm{mM} \mathrm{STZ}$ was added to the plate.
2.4. Detection of Superoxide Radical. Superoxide radicals were produced by reaction of the xanthine/xanthine oxidase system and reacted with spin trap DMPO. The DMPO- $\mathrm{OOH}$ adducts were detected using electron spin resonance (ESR) spectroscopy [29]. The ESR spectrum was recorded 2.5 min after mixing in a phosphate buffer solution ( $\mathrm{pH} 7.4$ ) with $6 \mathrm{M}$ DMPO $20 \mu \mathrm{l}$, xanthine oxidase $\left(0.25 \mathrm{U} \mathrm{ml}^{-1}\right) 20 \mu \mathrm{l}$, xanthine ( $5 \mathrm{mM}$ ) $20 \mu \mathrm{l}$ and KIOM-4 (final $50 \mu \mathrm{g} \mathrm{ml}^{-1}$ ) $20 \mu \mathrm{l}$ using JES-FA ESR spectrometer (JEOL, Tokyo, Japan).

2.5. Detection of Hydroxyl Radical. Hydroxyl radicals were generated by Fenton reaction. Hydroxyl radicals reacted with DMPO and the resultant DMPO-OH adducts were detected using an ESR spectrometer [29]. The ESR spectrum was recorded $2.5 \mathrm{~min}$ after mixing in a phosphate buffer solution ( $\mathrm{pH} 7.4$ ) with $0.2 \mathrm{ml}$ of $0.3 \mathrm{M}$ DMPO, $0.2 \mathrm{ml}$ of $10 \mathrm{mM}$ $\mathrm{FeSO}_{4}, 0.2 \mathrm{ml}$ of $10 \mathrm{mM} \mathrm{H} \mathrm{H}_{2}$ and KIOM-4 using ESR spectrometer.

2.6. Mitochondrial ROS Measurement. The RINm5F cells were seeded on to a 96-well plate at $2 \times 10^{4}$ cells/well. At $16 \mathrm{~h}$ after plating, the cells were treated with KIOM-4 at $50 \mu \mathrm{g} \mathrm{ml}^{-1}$, and $1 \mathrm{~h}$ later $10 \mathrm{mM} \mathrm{STZ}$ was added to the plate. The cells were incubated for an additional $30 \mathrm{~min}$ at $37^{\circ} \mathrm{C}$. After addition of $20 \mu \mathrm{M}$ of DHR 123 solution for $10 \mathrm{~min}$, the fluorescence was detected using a Perkin Elmer LS-5B spectrofluorometer and flow cytometer (Becton Dickinson, Mountain View, CA). For image analysis of the generation of mitochondrial ROS, the cells were seeded on a coverslip loaded six-well plate at $2 \times 10^{5}$ cells/well. At $16 \mathrm{~h}$ after plating, the cells were treated with KIOM-4, and $1 \mathrm{~h}$ later $10 \mathrm{mM}$ STZ was added to the plate. After changing the media, $20 \mu \mathrm{M}$ of DHR 123 was added to each well and the plate was incubated for an additional $30 \mathrm{~min}$ at $37^{\circ} \mathrm{C}$. After washing with $\mathrm{PBS}$, the stained cells were mounted onto a microscope slide in mounting medium (DAKO, Carpinteria, CA). Images were collected using the Laser Scanning Microscope 5 PASCAL program (Carl Zeiss, Jena, Germany) on a confocal microscope.

2.7. Cellular Mitochondrial Fractionation. Mitochondrial fractions were isolated by differential centrifugation using the mitochondria isolation kit (Active-Motif, Carlsbad, CA).

2.8. Measurement of Mn SOD Activity. The RINm5F cells were seeded on to a culture dish at a concentration of $1 \times$ $10^{5}$ cells $\mathrm{ml}^{-1}$, and at $16 \mathrm{~h}$ after plating were treated with KIOM-4 at $50 \mu \mathrm{g} \mathrm{ml}^{-1}$. After $1 \mathrm{~h}, 10 \mathrm{mM}$ STZ was added to the plate, which was incubated for a further $24 \mathrm{~h}$. The harvested cells were suspended in $10 \mathrm{mM}$ phosphate buffer $(\mathrm{pH}$ 7.5 ) and then lysed on ice by sonicating twice for $15 \mathrm{~s}$. Triton $\mathrm{X}-100(1 \%)$ was then added to the lysates and incubated for $10 \mathrm{~min}$ on ice. The lysates were clarified, by centrifugation at $5000 \mathrm{~g}$ for $30 \mathrm{~min}$ at $4^{\circ} \mathrm{C}$, and the protein content of the supernatant was determined. Fifty micrograms of protein was added to $500 \mathrm{mM}$ phosphate buffer ( $\mathrm{pH} \mathrm{10.2),}$ $1 \mathrm{mM}$ potassium cyanide (inhibitor of $\mathrm{Cu} \mathrm{Zn} \mathrm{SOD)}$ ) and 
$1 \mathrm{mM}$ epinephrine. Epinephrine rapidly undergoes autooxidation at $\mathrm{pH} 10$ to produce adrenochrome, a pink-colored product, which was assayed at $480 \mathrm{~nm}$ using a UV/VIS spectrophotometer in the kinetic mode. Mn SOD inhibits the auto-oxidation of epinephrine. The rate of inhibition was monitored at $480 \mathrm{~nm}$ and the amount of enzyme required to produce $50 \%$ inhibition was defined as one unit of enzyme activity, and the Mn SOD activity was expressed as units/mg protein [30].

2.9. Western Blot. Aliquots of the lysates ( $40 \mu \mathrm{g}$ of protein) were boiled for $5 \mathrm{~min}$ and electrophoresed on a $10 \%$ SDS-polyacrylamide gel. Blots in the gels were transferred onto nitrocellulose membranes (Bio-Rad, Hercules, CA). The nitrocellulose membrane was incubated with primary antibodies $(1: 1000)$ at $4^{\circ} \mathrm{C}$ overnight. Secondary antibody horseradish peroxidase conjugates $(1: 5000)$ (Pierce, Rockland, IL) were added, and incubated at room temperature for $1 \mathrm{~h}$, and exposed to X-ray film. Protein bands were detected using an enhanced chemiluminescence western blotting detection kit (Amersham, Little Chalfont, Buckinghamshire, UK).

2.10. Lipid Peroxidation Assay. Lipid peroxidation was assayed by determination of 8-isoprostane levels [31] in the culture medium, by use of a commercial enzyme immunoassay kit (Cayman Chemical, Ann Arbor, MI) according to the manufacturer's instructions.

2.11. Protein Carbonyl Formation. The amount of protein carbonyl formation was determined using an Oxiselect protein carbonyl ELISA kit purchased from Cell Biolabs (San Diego, CA) according to the manufacturer's instructions.

2.12. 8-Hydroxyl-2'-deoxyguanosine Assay. The amount of 8-hydroxyl-2'-deoxyguanosine (8-OHdG) was determined using a Bioxytech 8-OHdG-ELISA Kit purchased from OXIS Health Products (Portland, OR) according to the manufacturer's instructions.

2.13. Mitochondrial Membrane Potential Analysis. Mitochondrial membrane potential $(\Delta \psi)$ was analyzed using JC1, a lipophilic cationic fluorescence dye. Cells were harvested, and after changing the media, JC-1 was added to each well and incubated for an additional $30 \mathrm{~min}$ at $37^{\circ} \mathrm{C}$. After washing with PBS, the stained cells were assayed using flow cytometer. For image analysis of mitochondrial $\Delta \psi$, the stained cells were mounted onto microscope slide in mounting medium. Microscopic images were collected using the Laser Scanning Microscope 5 PASCAL program on confocal microscope [32].

2.14. Quantification of Cellular ATP Levels. The mitochondrial function was evaluated by measuring the cellular adenosine triphosphate (ATP) production in cells. The cells were harvested and washed twice with PBS. The harvested cells were then lysed on ice for $30 \mathrm{~min}$ in $200 \mu \mathrm{l}$ of lysis buffer [25 mM Tris (pH 7.8), $270 \mathrm{mM}$ sucrose, $1 \mathrm{mM}$ EDTA] by sonicating three times for $15 \mathrm{~s}$ and centrifuged at $4^{\circ} \mathrm{C}$ for $10 \mathrm{~min}$ at $16000 \mathrm{~g}$. Supernatants were collected from the lysates and ATP content was assayed using a luciferase/luciferin ATP determination kit (Molecular Probes, Eugene, OR) [33].

2.15. Mitochondrial Succinate Dehydrogenase Activity. To evaluate mitochondrial metabolic activity, mitochondrial succinate dehydrogenase activity was estimated by the MTT assay [34]. The cells were treated with KIOM-4 at $50 \mu \mathrm{g} \mathrm{ml}^{-1}$. After $1 \mathrm{~h}, 10 \mathrm{mM}$ of STZ, and the mixture was incubated for $24 \mathrm{~h}$. Fifty microliters of the [3-(4,5-dimethylthiazol-2yl)-2, 5-diphenyltetrazolium] bromide (MTT) stock solution $\left(2 \mathrm{mg} \mathrm{ml}^{-1}\right)$ was then added into each well to attain a total reaction volume of $200 \mu \mathrm{l}$. After incubating for $4 \mathrm{~h}$, the plate was centrifuged at $800 \mathrm{~g}$ for $5 \mathrm{~min}$ and the supernatants were aspirated. The formazan crystals in each well were dissolved in $150 \mu \mathrm{l}$ of dimethylsulfoxide and read at $\mathrm{A}_{540}$ on a scanning multi-well spectrophotometer [35].

2.16. Measurements of Insulin Levels. The cells were treated with KIOM-4 at $50 \mu \mathrm{g} \mathrm{ml}^{-1}$, and $1 \mathrm{~h}$ later $10 \mathrm{mM} \mathrm{STZ}$ was added to the plate, and the mixture was incubated for $24 \mathrm{~h}$. The amount of insulin was determined by using an ELISA rat specific insulin enzyme immunoassay kit (Spi-Bio, Massy, France).

2.17. Statistical Analysis. All the measurements were made in triplicate and all values are represented as the mean \pm standard error of the mean (SEM). Data were subjected to an analysis of the variance (ANOVA) using the Tukey test to analyze the difference. A $P$-value of $<.05$ was considered significant.

\section{Results}

3.1. Radical Scavenging Activity of KIOM-4 in a Cell-Free System. Our previous result showed that the intracellular ROS scavenging activity of KIOM- 4 was 48,55 and $66 \%$ at concentrations of 10,50 and $100 \mu \mathrm{g} \mathrm{ml}^{-1}$, respectively [24]. And KIOM-4 at concentrations of $100 \mu \mathrm{g} \mathrm{ml}^{-1}$ showed some cytotoxicity (data not shown). Therefore, we determined to choose $50 \mu \mathrm{g} \mathrm{ml}^{-1}$ as optimal dose for further study. The radical scavenging effects of KIOM-4 on superoxide radicals and hydroxyl radicals were measured. Superoxide radicals produced by the xanthine/xanthine oxidase system and the hydroxyl radicals generated by the Fenton reaction $\left(\mathrm{FeSO}_{4}+\right.$ $\mathrm{H}_{2} \mathrm{O}_{2}$ ) in a cell-free system were detected by ESR spectrometry. The ESR results revealed no clear signal in the control and the $50 \mu \mathrm{g} \mathrm{ml}^{-1}$ of KIOM-4; however, the superoxide radical signal increased to 646 in the xanthine/xanthine oxidase system. KIOM-4 treatment decreased the superoxide radical signal to 209 (Figure 1(a)). In addition, the hydroxyl radical signal increased to 2809 in the $\mathrm{FeSO}_{4}+\mathrm{H}_{2} \mathrm{O}_{2}$ system. KIOM4 treatment decreased the hydroxyl radical signal to 386 (Figure 1(b)). 


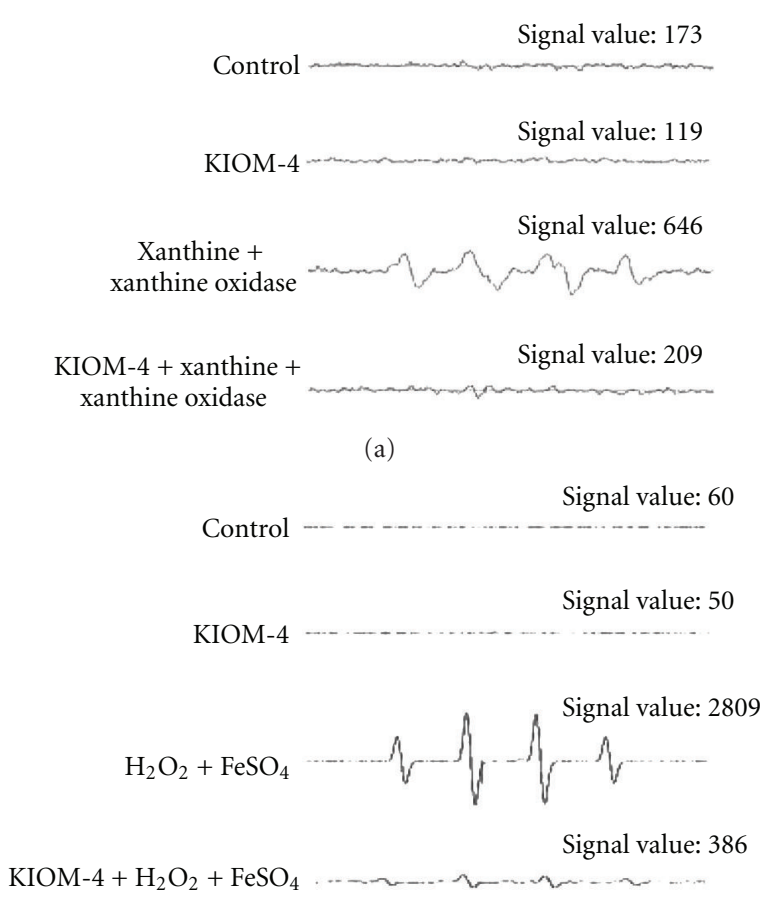

(b)

FIgURE 1: The effect of KIOM-4 on cell-free generation of superoxide and hydroxyl radicals. (a) Superoxide radicals were generated by xanthine/xanthine oxidase and reacted with DMPO; the resultant DMPO-OOH adducts were detected using an ESR spectrometer. (b) Hydroxyl radicals were generated by the Fenton reaction $\left(\mathrm{H}_{2} \mathrm{O}_{2} / \mathrm{FeSO}_{4}\right)$ and reacted with DMPO; the resultant DMPO-OH adducts were detected using an ESR spectrometer.

\subsection{Reduction of Mitochondrial ROS by KIOM-4 Treatment.} The fluorescence dye DHR 123 was used to detect mitochondrial ROS in cells after STZ treatment. The fluorescence spectrometric data revealed that STZ treatment increased the level of mitochondrial ROS compared with control. However, treatment with KIOM-4 at $50 \mu \mathrm{g} \mathrm{ml}^{-1}$ attenuated the STZ-induced ROS increase (Figure 2(a)). In addition, flow cytometry revealed a fluorescence intensity of 106 for ROS in STZ-treated cells with KIOM-4 at $50 \mu \mathrm{g} \mathrm{ml}^{-1}$, compared with a fluorescence intensity of 533 in STZtreated cells (Figure 2(b)). Confocal microscopy revealed that KIOM-4 reduced the red fluorescence intensity of STZ-induced mitochondrial ROS (Figure 2(c)). These data suggest that KIOM-4 had mitochondrial ROS scavenging properties.

\subsection{Induction of $\mathrm{Mn} S O D$ and Its Transcription Factor by} KIOM-4 Treatment. Mn SOD acts as a first defense system to protect mitochondria and other cellular components as it scavenges superoxide anion in the mitochondrial matrix [36]. As shown in Figure 3(a), Mn SOD activity was $30 \mathrm{U} \mathrm{mg}^{-1}$ protein with $50 \mu \mathrm{g} \mathrm{ml}^{-1}$ of KIOM-4, compared with $26 \mathrm{U} \mathrm{mg}^{-1}$ protein in the control. STZ treatment decreased the SOD activity to $12 \mathrm{U} \mathrm{mg}^{-1}$ protein; however, treatment with KIOM-4 increased this activity to $20 \mathrm{U} \mathrm{mg}^{-1}$ protein. In addition, western blot data revealed that STZ treatment decreased the expression of Mn SOD compared with control. KIOM-4 treatment at $50 \mu \mathrm{g} \mathrm{ml}^{-1}$ increased the Mn SOD level attenuated by STZ treatment (Figure 3(b)). $\mathrm{Mn}$ SOD has an antioxidant response element (ARE) sequence in its promoter region. Nrf2 is an important transcription factor that regulates ARE-driven Mn SOD expression. Nuclear Nrf2 expression was decreased by STZ treatment; however, KIOM-4 treatment cells increased the nuclear Nrf2 expression (Figure 3(c)). These data suggest that KIOM-4 exhibited induction of Mn SOD via activation of Nrf2.

3.4. Protection of Damaged Mitochondrial Components by KIOM-4 Treatment. The level of 8-isoprostan, a marker of lipid peroxidation, is increased to $230 \mathrm{pg} \mathrm{ml}^{-1}$ in cells exposed to STZ, compared with $159 \mathrm{pg} \mathrm{ml}^{-1}$ in control cells. KIOM-4, however, decreased this level to $161 \mathrm{pg} \mathrm{ml}^{-1}$ in STZ-treated cells (Figure 4(a)). The mitochondrial protein carbonyl content, which is marker of protein modification [37], increased significantly after STZ treatment, and KIOM4 prevented the STZ-induced protein carbonyl formation (Figure 4(b)). STZ treatment increased the amount of 8OHdG, which is marker of base modification in DNA [38], to $2006 \mathrm{pg} \mathrm{ml}^{-1}$ compared with $247 \mathrm{pg} \mathrm{ml}^{-1}$ in control cells, and KIOM-4 decreased 8-OHdG to $777 \mathrm{pg} \mathrm{ml}^{-1}$ in STZtreated cells (Figure 4(c)). These data suggest that KIOM4 provides protection against STZ-induced mitochondrial damages.

3.5. Recovery of Disrupted Mitochondrial $\Delta \psi$ and Its Related Protein by KIOM-4 Treatment. The mitochondrial $\Delta \psi$, which is a marker of mitochondrial membrane integrity, was detected using flow cytometry and confocal microscopy after staining with the fluorescence dye JC- 1 . The flow cytometric data showed that the STZ treatment resulted in the loss of $\Delta \psi$, as substantiated by an increase in fluorescence (FL-1) with JC-1. KIOM-4 treatment blocked the loss of $\Delta \psi$ in STZ-treated cells. The fluorescence intensity was 301 value in STZ-treated cells with $50 \mu \mathrm{g} \mathrm{ml}^{-1}$ of KIOM-4, compared with a fluorescence intensity of 586 in STZ-treated cells (Figure 5(a)). In addition, the confocal microscopy data showed that control cells and cells treated with KIOM-4 only exhibited strong red fluorescence in the mitochondria after JC-1 staining, indicating that mitochondrial $\Delta \psi$ was in the polarized state (Figure 5(b), left panel). However, STZ treatment resulted in decreased red fluorescence in the mitochondria and increased green fluorescence, suggesting that STZ treatment disrupted the mitochondrial $\Delta \psi$ to a depolarized state. KIOM-4 treatment decreased the green fluorescence in STZ-treated cells (Figure 5(b), right panel), indicating that KIOM-4 inhibited the loss of $\Delta \psi$ in response to STZ treatment. The pore opening induces the loss of $\Delta \psi$, which in turn induces the release of cytochrome $\mathrm{c}$ from the mitochondria and most commonly leads to apoptotic cell death [39]. KIOM-4 inhibited the STZ-induced release of cytochrome $\mathrm{c}$ from the mitochondria into the cytosol 


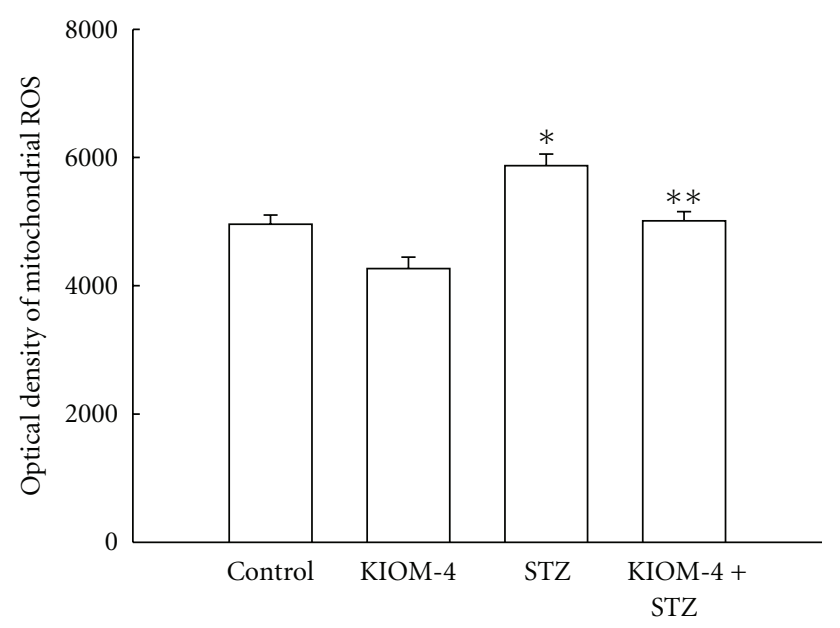

(a)

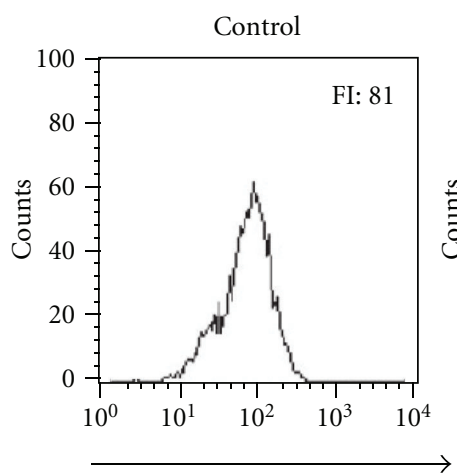

Increase of mitochondrial ROS
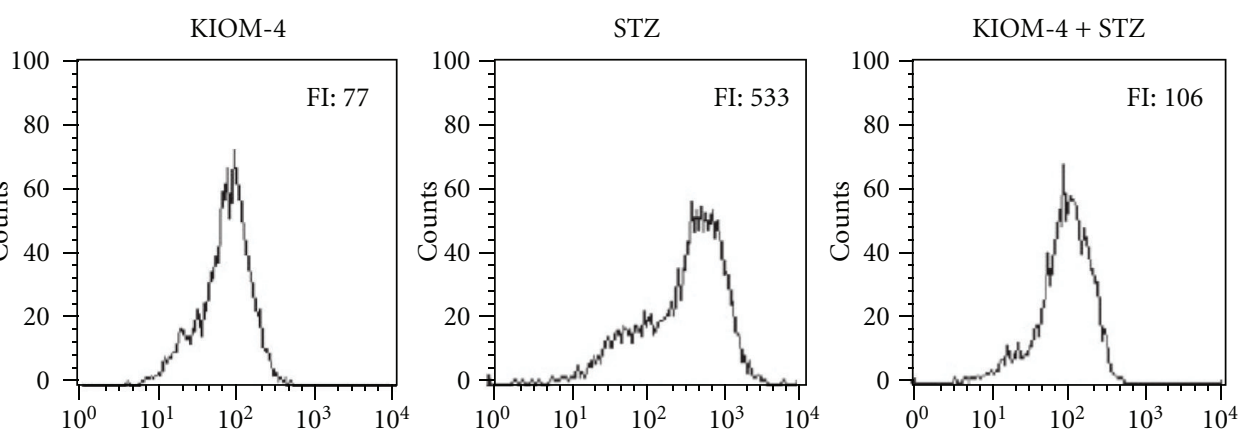

(b)
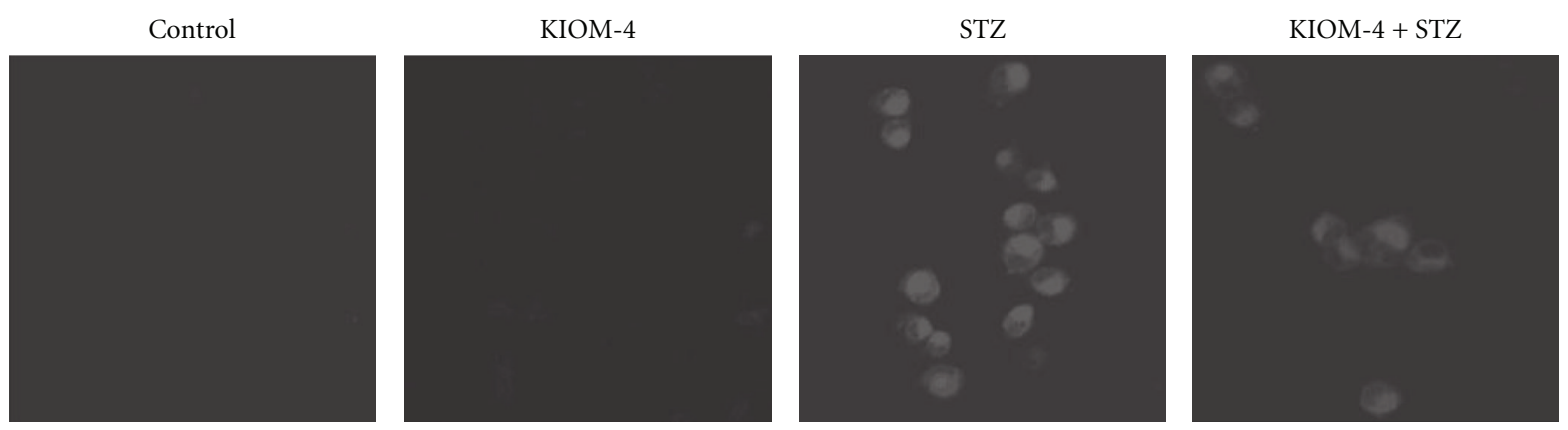

(c)

FIGURE 2: The effect of KIOM-4 on STZ-induced mitochondrial ROS generation. The cells were treated with KIOM-4 at $50 \mu \mathrm{g}$ ml ${ }^{-1}$. After $1 \mathrm{~h}, 10 \mathrm{mM}$ of STZ was added to the plate. After an additional $30 \mathrm{~min}$, the mitochondrial ROS were detected by spectrofluorometry (a) and flow cytometry (b) after DHR 123 treatment. FI indicates the fluorescence intensity of DHR 123. (c) The representative confocal images illustrate the increase in red fluorescence intensity of DHR 123 produced by ROS in STZ-treated cells s compared with that in control and the lowered fluorescence intensity in STZ-treated cells with KIOM-4 (original magnification $\times 400$ ). The measurements were made in triplicate and the values were expressed as means \pm SEM. Asterisk represents significantly different from control cells $(P<.05)$ and double asterisk represent significantly different from STZ-treated cells $(P<.05)$.

(Figure 5(c)). These results suggest that KIOM-4 protected against STZ-damage to mitochondrial $\Delta \psi$.

3.6. Enhancement of Decreased Intracellular ATP Level, Mitochondrial Enzymes, and Insulin Secretion by KIOM-4 Treatment. Mitochondrial injury is followed by the depletion of intracellular ATP and mitochondrial enzymes. As shown in Figure 6(a), STZ treatment reduced the ATP level compared with that in control cells; however, KIOM-4 treatment recovered the ATP level in STZ-treated cells. Mitochondrial succinate dehydrogenase activity was decreased in STZtreated cells; however, KIOM-4 treatment of STZ-treated 


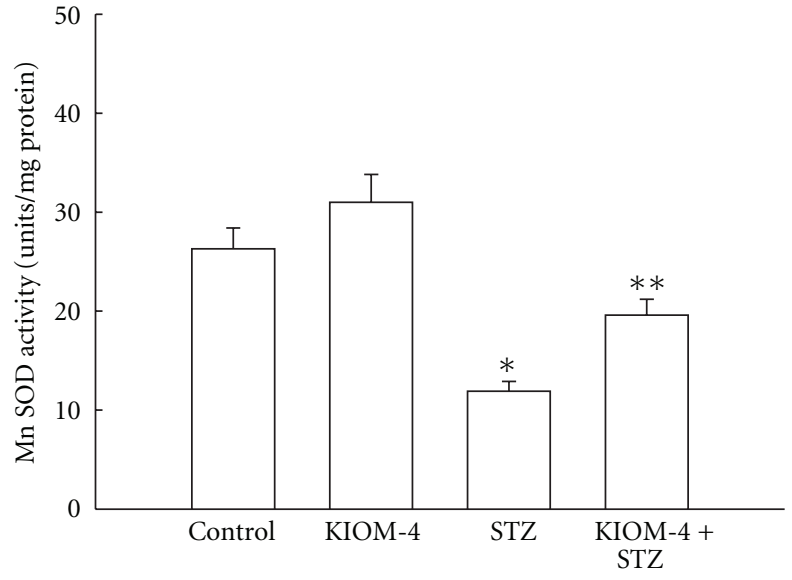

(a)

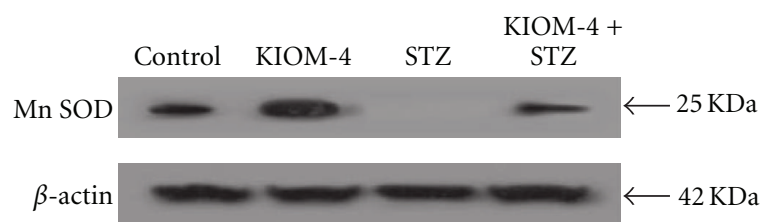

(b)

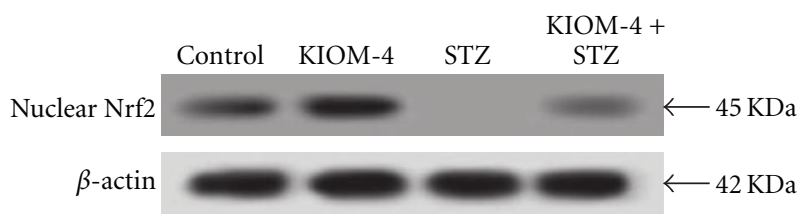

(c)

FIGURE 3: The effect of KIOM-4 on Mn SOD and its transcription factor. (a) The enzyme activities are expressed as average enzyme unit per mg protein \pm SEM. Western blot analysis was performed using anti-Mn SOD (b) and Nrf2 (c) antibody. Asterisk represent significantly different from control cells $(P<.05)$ and double asterisk represent significantly different from STZ-treated cells $(P$ $<.05)$.

cells enhanced this activity (Figure 6(b)). Furthermore, STZ decreased the insulin level of RINm5F, which secretes insulin, however, KIOM-4 treatment of STZ-treated cells enhanced insulin secretion (Figure 6(c)). These results suggest that KIOM-4 attenuates mitochondrial dysfunction in STZinduced diabetic cells.

\section{Discussion}

Mitochondrial radical production and consequent oxidative damage contribute to the progressive and pathophysiological conditions of diabetes. It has been suggested that mitochondrial ROS induced by high glucose might cause the pathogenesis of diabetes mellitus and its complications through modification of various mitochondrial events [40]. Consequently, therapeutic strategies to decrease ROS production or to intercept these ROS should be explored [41]. Numerous studies have reported that antioxidant treatment, which targets oxidative stress, may help prevent or delay

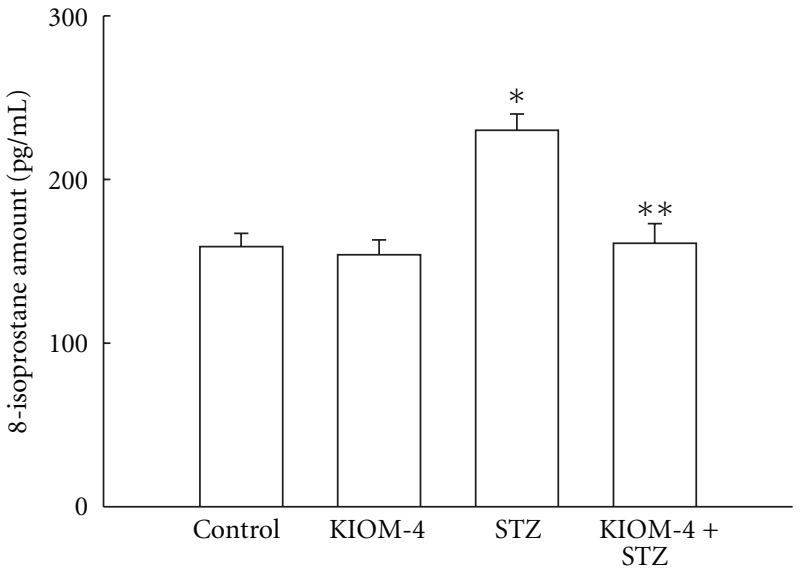

(a)

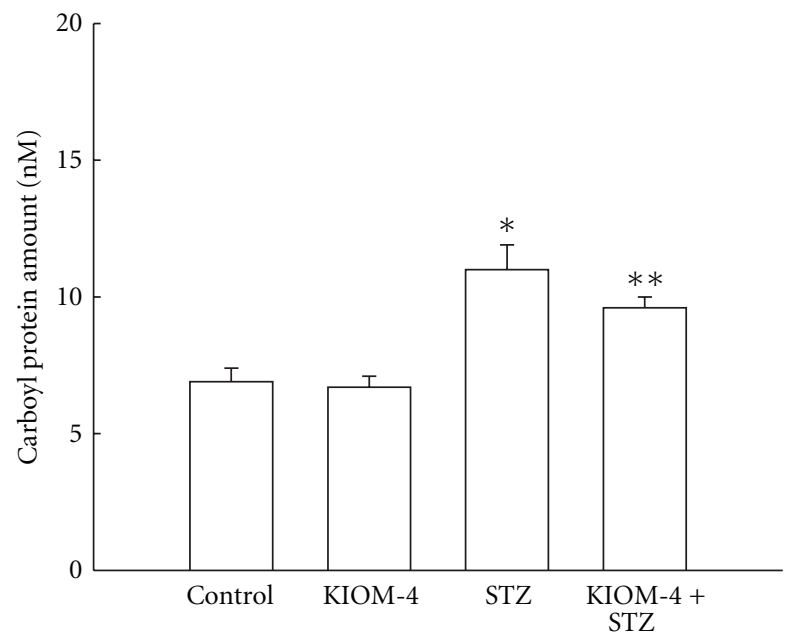

(b)

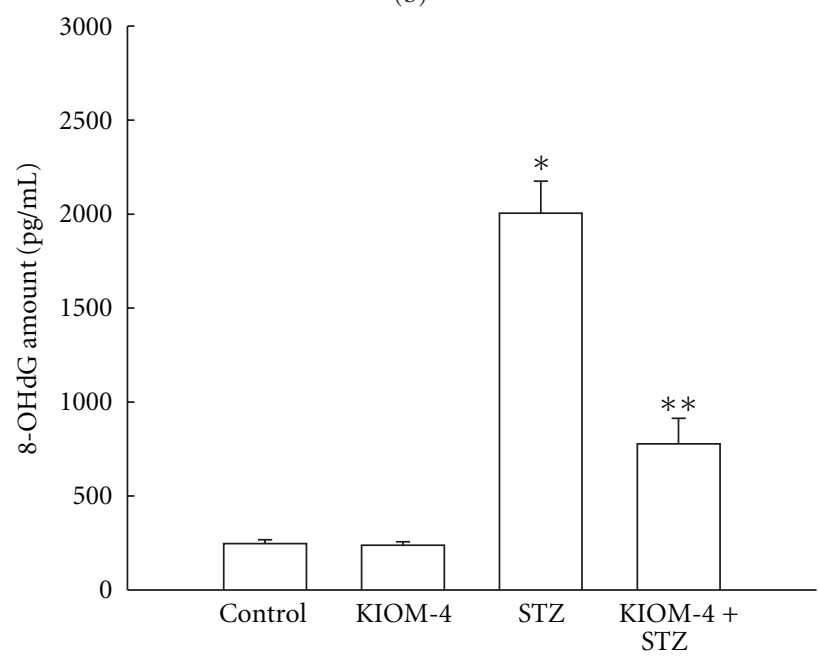

(c)

FIGURE 4: The effect of KIOM-4 on STZ-induced mitochondrial lipid, protein and DNA damage. (a) Lipid peroxidation was detected by measuring the amount of 8 -isoprostane. (b) Protein oxidation was assayed by measuring carbonyl formation. (c) DNA damage was detected measuring the amount of $8-\mathrm{OHdG}$. Asterisk represent significantly different from control cells $(P<.05)$ and double asterisk represent significantly different from STZ-treated cells $(P$ $<.05)$. 


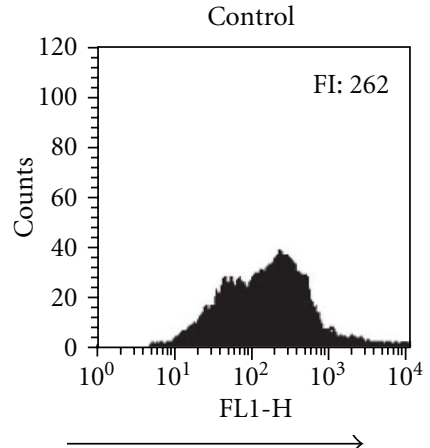

Loss of mitochondrial $\Delta \psi$
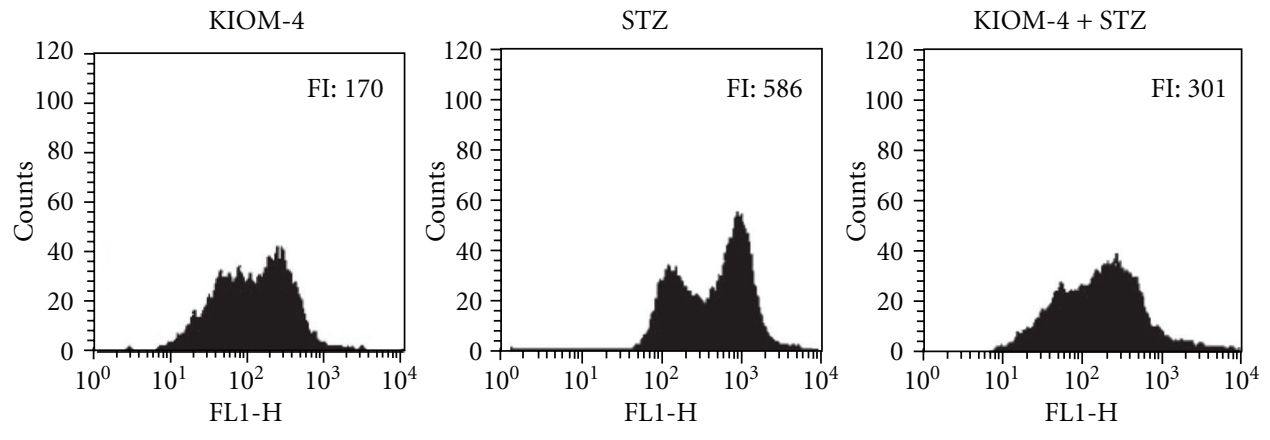

(a)

Mitochondrial $\Delta \psi$
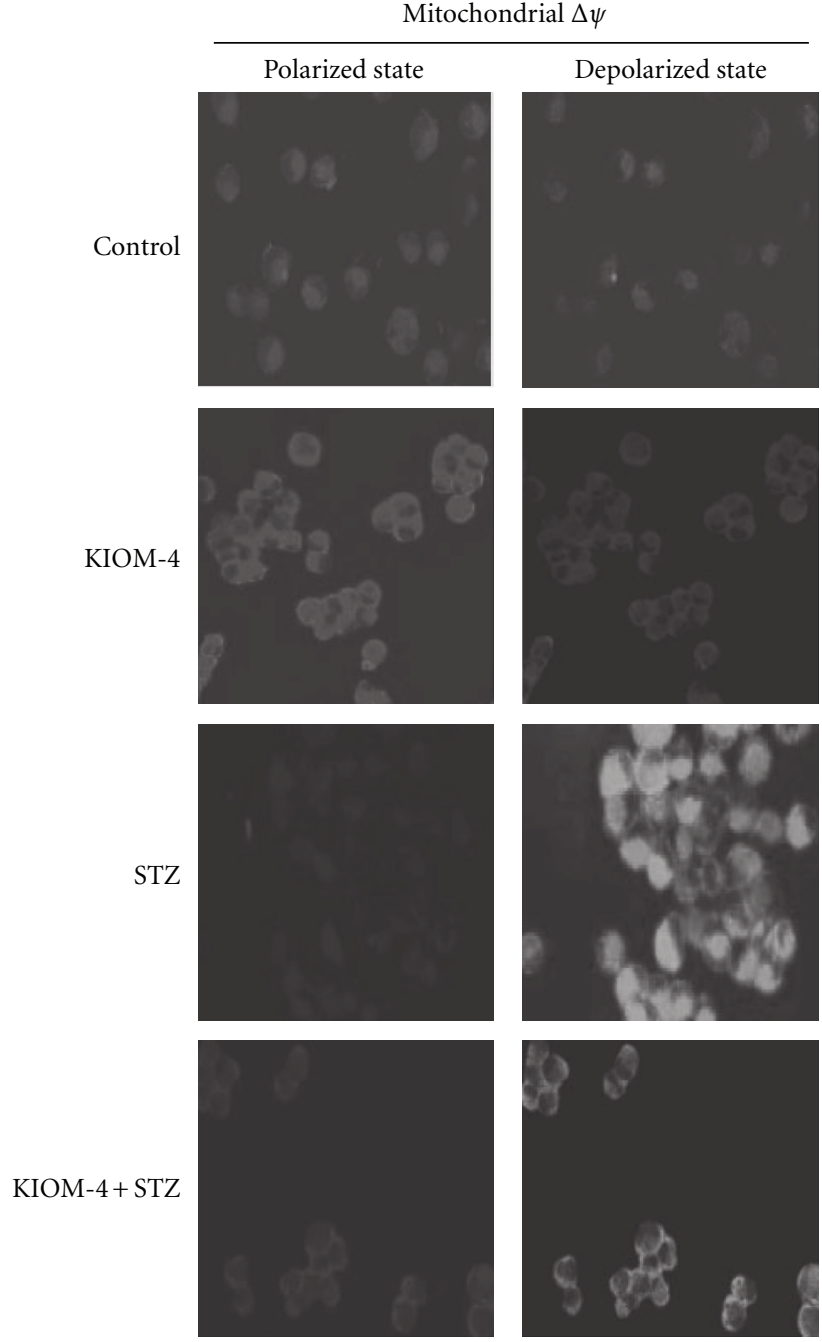

(b)

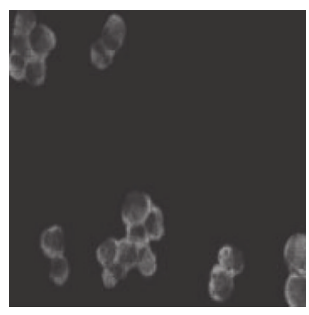

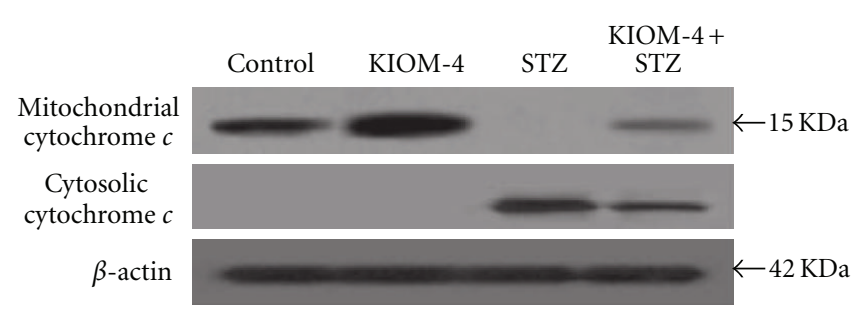

(c)

FIGURE 5: The effect of KIOM-4 on mitochondrial $\Delta \psi$ and its related proteins. The mitochondrial $\Delta \psi$ was analyzed using (a) flow cytometry and (b) confocal microscopy after staining cells with JC-1 dye. Western blot analysis was performed using anti-cytochrome c (c) antibody.

the development of diabetes and its complications [42, 43]. In this context, the possible anti-diabetic effects of KIOM4 on the oxidative mitochondrial damage induced by STZ treatment in pancreatic $\beta$-cells were elucidated. In this study, KIOM-4 exhibited significant ROS radical scavenging activity against superoxide and hydroxyl radicals. Moreover, KIOM-4 attenuated the STZ-induced increase in mitochondrial ROS. Mn SOD is located in the mitochondrial matrix 


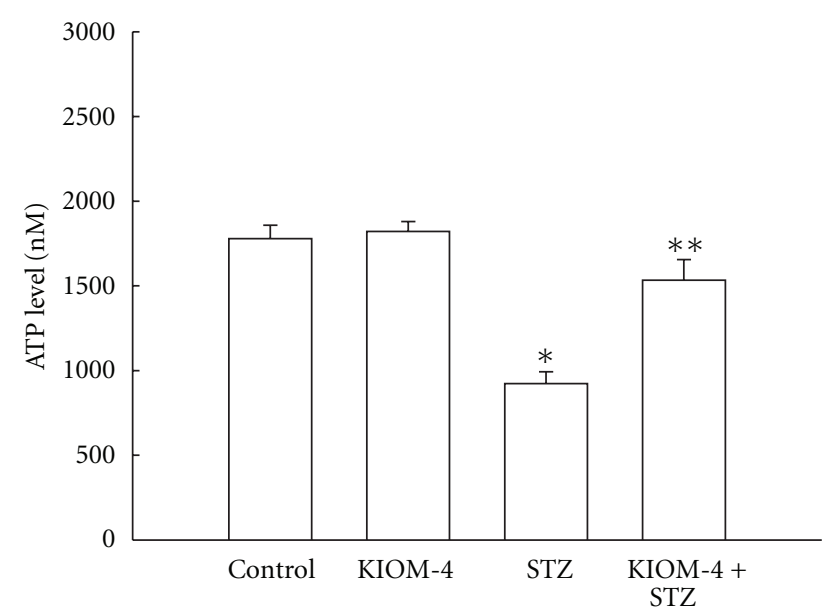

(a)

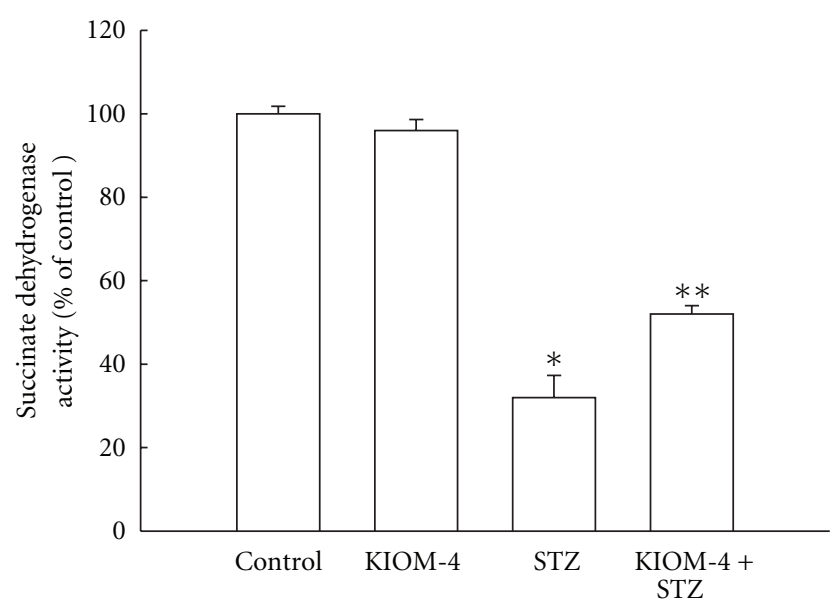

(b)

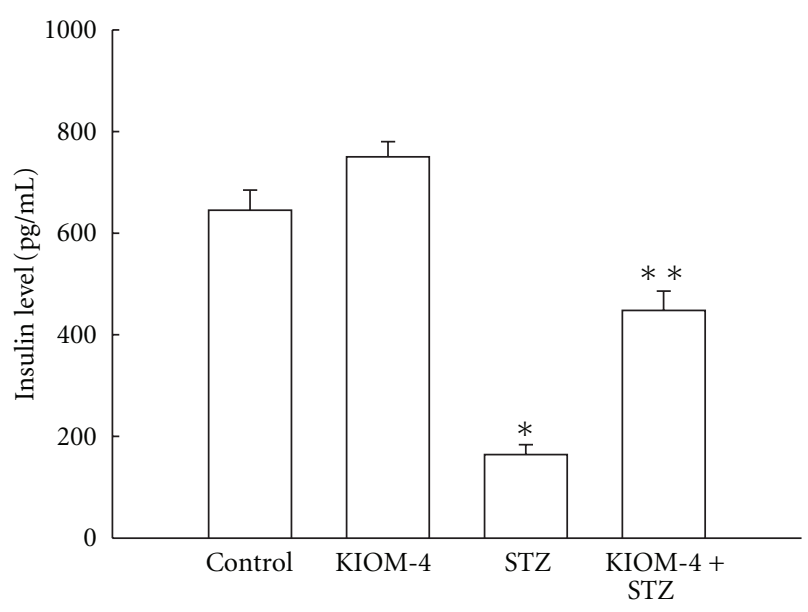

(c)

FIgUre 6: The effect of KIOM-4 on intracellular ATP level, mitochondrial enzyme, and insulin level. (a) ATP content was assayed using a luciferase/luciferin ATP determination kit. (b) Mitochondrial succinate dehydrogenase activity was estimated by the MTT assay. (c) The amount of insulin was determined by using an ELISA rat specific insulin enzyme immunoassay kit. Asterisk represent significantly different from control cells $(P<.05)$ and double asterisk represent significantly different from STZ-treated cells $(P<.05)$.

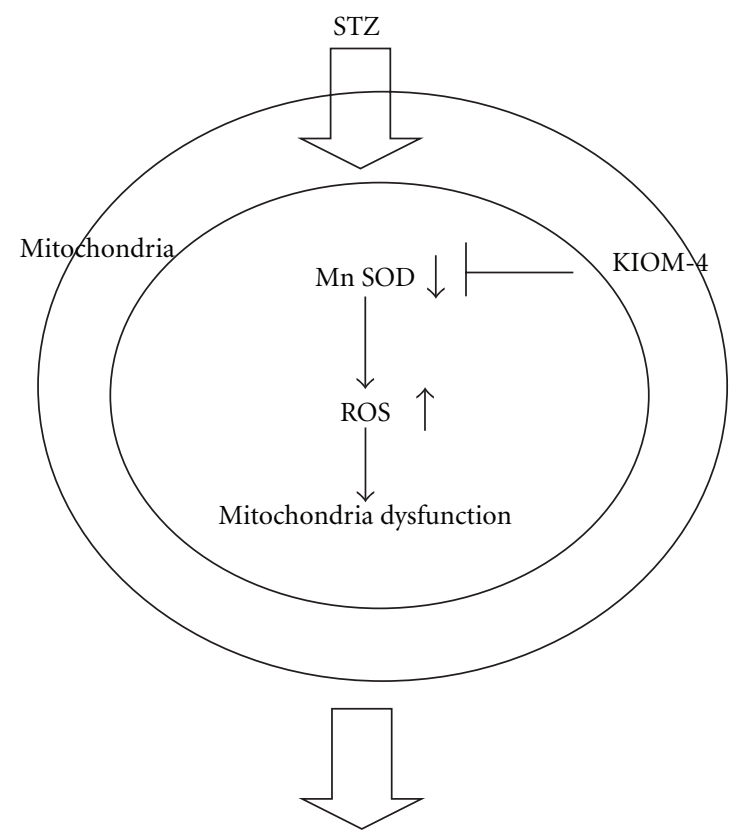

Mitochondrial damage

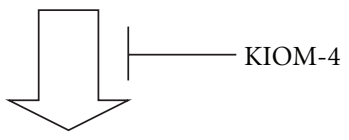

Diabetes

Figure 7: A proposed pathway for protective effect of KIOM-4 against STZ-induced mitochondrial oxidative stress in pancreatic $\beta$ cells via its antioxidant effects.

and is the primary SOD isoform that dismutates superoxide anions generated by the mitochondrial respiratory chain [44]. Pancreatic cells contain relatively low levels of antioxidant enzymes, making these cells more vulnerable to oxidative stress $[42,45]$. A significant imbalance between ROS production and endogenous Mn SOD has been confirmed by the reduced activity and protein expression of Mn SOD in STZ-treated cells. In diabetes, decreased Mn SOD activity promotes the damage to cellular components such as lipid, protein and DNA [46]. Treatment with KIOM-4 restored the Mn SOD activity decreased by STZ. In addition, our previous study suggested that KIOM- 4 exhibited cytoprotective effects against STZ-induced oxidative stress damage in $\beta$-cells via the activation of catalase and heme oxygenase- 1 [27, 28]. Meanwhile, Nrf2 is able to activate the antioxidantresponsive element (ARE)-dependent gene expression in order to maintain cellular redox homeostasis [47]. Nrf2 is an important transcription factor that regulates AREdriven expression of antioxidant genes, including Mn SOD. Nuclear Nrf2 expression was decreased by STZ treatment; however, KIOM-4 treatment recovered the nuclear Nrf2 expression. The components in the mitochondrial matrix are highly susceptible to an oxidative environment [48]. KIOM-4 prevented the STZ-induced mitochondrial lipid peroxidation, protein carbonyl and DNA modification. In general, mitochondrial DNA is more vulnerable to oxidative 
stress, and the subsequent damage is more extensive than that in nuclear DNA due to the lack of protective histones and low repair mechanisms $[45,46]$. Elevated oxidative stress can increase the membrane permeability of the mitochondria by opening pores in the inner mitochondrial membrane, and can lead to the loss of $\Delta \psi$ [49]. The loss of mitochondrial $\Delta \psi$ can cause the release of cytochrome $\mathrm{c}$ and the activation of the apoptotic pathway [50]. Indeed, STZ treatment disrupted the mitochondrial $\Delta \psi$ and resulted in the release of mitochondrial cytochrome $c$ to cytosol. However, KIOM-4 prevented the sequential mitochondrial damage process induced by STZ treatment. The elevated level of mitochondrial ROS generated by STZ acts as a powerful oxidant and causes damage to mitochondrial respiratory chain complexes. As mitochondria are the major producers of ATP, mitochondrial dysfunction also leads to reduced ATP levels [51]. Depletion of ATP content was observed in STZtreated cells as a consequence of impaired mitochondrial respiratory chain activity. Succinate dehydrogenase is a mitochondrial TCA cycle enzyme and its activity is mainly regulated by ATP [52]. KIOM-4 treatment restored the ATP content and the succinate dehydrogenase activity, which were both reduced by STZ treatment. It has been reported that STZ treatment can increase mitochondrial ROS in rat pancreatic tissue, and the mitochondrial oxidative stress reduces insulin secretion by pancreatic $\beta$-cells $[12,53]$. KIOM-4 significantly increased insulin content decreased by STZ treatment.

Hence, these results suggest that KIOM-4 protects against ROS-mediated mitochondrial dysfunction in diabetic pancreatic $\beta$-cells by scavenging ROS and inducing mitochondrial antioxidant enzymes (Figure 7).

\section{Funding}

Korea Institute of Oriental Medicine (grant no. K09030).

\section{Acknowledgment}

K. A. Kang and J. S. Kim contribute equally to this work.

\section{References}

[1] D. C. Wallace, "Mitochondrial diseases in man and mouse," Science, vol. 283, no. 5407, pp. 1482-1488, 1999.

[2] B. S. Kristal, C. T. Jackson, H.-Y. Chung, M. Matsuda, H. D. Nguyen, and B. P. Yu, "Defects at center P underlie diabetesassociated mitochondrial dysfunction," Free Radical Biology and Medicine, vol. 22, no. 5, pp. 823-833, 1997.

[3] T. Nishikawa, D. Edelstein, X. L. Du et al., "Normalizing mitochondrial superoxide production blocks three pathways of hyperglycaemic damage," Nature, vol. 404, no. 6779, pp. 787-790, 2000.

[4] M. A. Moro, A. Almeida, J. P. Bolaños, and I. Lizasoain, "Mitochondrial respiratory chain and free radical generation in stroke," Free Radical Biology and Medicine, vol. 39, no. 10, pp. 1291-1304, 2005.

[5] P. Singh, A. Jain, and G. Kaur, "Impact of hypoglycemia and diabetes on CNS: correlation of mitochondrial oxidative stress with DNA damage," Molecular and Cellular Biochemistry, vol. 260, no. 1, pp. 153-159, 2004.

[6] P. Ježek and L. Hlavatá, "Mitochondria in homeostasis of reactive oxygen species in cell, tissues, and organism," International Journal of Biochemistry and Cell Biology, vol. 37, no. 12, pp. 2478-2503, 2005.

[7] D. J. P. Barker and C. Osmond, "Infant mortality, childhood nutrition, and ischaemic heart disease in England and Wales," The Lancet, vol. 1, no. 8489, pp. 1077-1081, 1986.

[8] T. Nishikawa, D. Edelstein, and M. Brownlee, "The missing link: a single unifying mechanism for diabetic complications," Kidney International, vol. 58, no. 77, pp. S26-S30, 2000.

[9] M. Brownlee, "Biochemistry and molecular cell biology of diabetic complications," Nature, vol. 414, no. 6865, pp. 813820, 2001.

[10] T. Ohkuwa, Y. Sato, and M. Naoi, "Hydroxyl radical formation in diabetic rats induced by streptozotocin," Life Sciences, vol. 56, no. 21, pp. 1789-1798, 1995.

[11] X. Chen, R. M. Touyz, J. B. Park, and E. L. Schiffrin, "Antioxidant effects of vitamins $\mathrm{C}$ and $\mathrm{E}$ are associated with altered activation of vascular NADPH oxidase and superoxide dismutase in stroke-prone SHR," Hypertension, vol. 38, no. 3, pp. 606-611, 2001.

[12] H. Raza, S. K. Prabu, M.-A. Robin, and N. G. Avadhani, "Elevated mitochondrial cytochrome P450 2E1 and glutathione S-transferase A4-4 in streptozotocin-induced diabetic rats tissue-specific variations and roles in oxidative stress," Diabetes, vol. 53, no. 1, pp. 185-194, 2004.

[13] J. Saito, Y. Sakai, and H. Nagase, "In vitro anti-mutagenic effect of magnolol against direct and indirect mutagens," Mutation Research, vol. 609, no. 1, pp. 68-73, 2006.

[14] E.-J. Park, S.-Y. Kim, Y.-Z. Zhao, and D. H. Sohn, "Honokiol reduces oxidative stress, c-jun-NH2-terminal kinase phosphorylation and protects against glycochenodeoxycholic acid-induced apoptosis in primary cultured rat hepatocytes," Planta Medica, vol. 72, no. 7, pp. 661-664, 2006.

[15] A. H. Cao, L. T. Vo, and R. G. King, "Honokiol protects against carbon tetrachloride induced liver damage in the rat," Phytotherapy Research, vol. 19, no. 11, pp. 932-937, 2005.

[16] Y.-R. Lin, H.-H. Chen, C.-H. Ko, and M.-H. Chan, "Neuroprotective activity of honokiol and magnolol in cerebellar granule cell damage," European Journal of Pharmacology, vol. 537, no. 1-3, pp. 64-69, 2006.

[17] J. Lee, E. Jung, J. Park et al., "Anti-inflammatory effects of magnolol and honokiol are mediated through inhibition of the downstream pathway of MEKK-1 in NF- $\kappa$ B activation signaling," Planta Medica, vol. 71, no. 4, pp. 338-343, 2005.

[18] K. Y. Ho, C. C. Tsai, C. P. Chen, J. S. Huang, and C. C. Lin, "Antimicrobial activity of honokiol and magnolol isolated from Magnolia officinalis," Phytotherapy Research, vol. 15, no. 2, pp. 139-141, 2001.

[19] M. Miyazawa, K. Sakano, S.-I. Nakamura, and H. Kosaka, "Antimutagenic activity of isoflavone from Pueraria lobata," Journal of Agricultural and Food Chemistry, vol. 49, no. 1, pp. 336-341, 2001.

[20] K. T. Lee, I. C. Sohn, D. H. Kim, J. W. Choi, S. H. Kwon, and H. J. Park, "Hypoglycemic and hypolipidemic effects of tectorigenin and kaikasaponin III in the streptozotocinlnduced diabetic rat and their antioxidant activity in vitro," Archives of Pharmacal Research, vol. 23, no. 5, pp. 461-466, 2000.

[21] K.-T. Lee, I.-C. Sohn, Y.-K. Kim et al., "Tectorigenin, an isoflavone of Pueraria thunbergiana BENTH., induces differentiation and apoptosis in human promyelocytic leukemia 
HL-60 cells," Biological and Pharmaceutical Bulletin, vol. 24, no. 10, pp. 1117-1121, 2001.

[22] H. Liao, L. K. Banbury, and D. N. Leach, "Elucidation of Danzhixiaoyao Wan and its constituent herbs on antioxidant activity and inhibition of nitric oxide production," EvidenceBased Complementary and Alternative Medicine, vol. 4, no. 4, pp. 425-430, 2007.

[23] Z. Y. Wang and D. W. Nixon, "Licorice and cancer," Nutrition and Cancer, vol. 39, no. 1, pp. 1-11, 2001.

[24] D. G. Popovich, S. Y. Yeo, and W. Zhang, "Ginseng (Panax quinquefolius) and Licorice (Glycyrrhiza uralensis) root extract combinations increase hepatocarcinoma cell (Hep-G2) viability," Evidence-Based Complementary and Alternative Medicine. In press.

[25] M. J. Ahn, C. Y. Kim, J. S. Lee et al., "Inhibition of HIV1 integrase by galloyl glucoses from Terminalia chebula and flavonol glycoside gallates from Euphorbia pekinensis," Planta Medica, vol. 68, no. 5, pp. 457-459, 2002.

[26] L.-Y. Kong, Y. Li, X.-L. Wu, and Z.-D. Min, "Cytotoxic diterpenoids from Euphorbia pekinensis," Planta Medica, vol. 68, no. 3, pp. 249-252, 2002.

[27] K. A. Kang, J. S. Kim, and J. W. Hyun, "KIOM-4 protects RINm5F pancreatic $\beta$-cells against streptozotocin induced oxidative stress in vitro," Biotechnology and Bioprocess Engineering, vol. 13, no. 2, pp. 150-157, 2008.

[28] K. A. Kang, J. S. Kim, R. Zhang et al., "Protective mechanism of KIOM-4 against streptozotocin induced diabetic cells: involvement of heme oxygenase-1," Biotechnology and Bioprocess Engineering, vol. 14, no. 3, pp. 295-301, 2009.

[29] Y. Yoshimura, T. Inomata, H. Nakazawa, H. Kubo, F. Yamaguchi, and T. Ariga, "Evaluation of free radical scavenging activities of antioxidants with an $\mathrm{H}_{2} \mathrm{O}_{2} / \mathrm{NaOH} / \mathrm{DMSO}$ system by electron spin resonance," Journal of Agricultural and Food Chemistry, vol. 47, no. 11, pp. 4653-4656, 1999.

[30] L. M. Casano, M. Martin, and B. Sabater, "Sensitivity of superoxide dismutase transcript levels and activities to oxidative stress is lower in mature-senescent than in young barley leaves," Plant Physiology, vol. 106, no. 3, pp. 1033-1039, 1994.

[31] R. Manzer, J. Wang, K. Nishina, G. McConville, and R. J. Mason, "Alveolar epithelial cells secrete chemokines in response to IL-1 $\beta$ and lipopolysaccharide but not to ozone," American Journal of Respiratory Cell and Molecular Biology, vol. 34, no. 2, pp. 158-166, 2006.

[32] A. Cossarizza, M. Baccarani-Contri, G. Kalashnikova, and C. Franceschi, "A new method for the cytofluorimetric analysis of mitochondrial membrane potential using the J-aggregate forming lipophilic cation 5,5',6,6'-tetrachloro1,1,3,3'-tetraethylbenzimidazolcarbocyanine iodide (JC-1)," Biochemical and Biophysical Research Communications, vol. 197, no. 1, pp. 40-45, 1993.

[33] B. P. Connop, R. L. Thies, K. Beyreuther, N. Ida, and P. B. Reiner, "Novel effects of FCCP [carbonyl cyanide p(trifluoromethoxy)phenylhydrazone] on amyloid precursor protein processing," Journal of Neurochemistry, vol. 72, no. 4, pp. 1457-1465, 1999.

[34] J. C. Wataha, C. T. Hanks, and R. G. Craig, "The in vitro effects of metal cations on eukaryotic cell metabolism," Journal of Biomedical Materials Research, vol. 25, no. 9, pp. 1133-1149, 1991.

[35] J. Carmichael, W. G. DeGraff, and A. F. Gazdar, "Evaluation of a tetrazolium-based semiautomated colorimetric assay: assessment of chemosensitivity testing," Cancer Research, vol. 47, no. 4, pp. 936-942, 1987.
[36] I. Fridovich, "Superoxide radical and superoxide dismutases," Annual Review of Biochemistry, vol. 64, pp. 97-112, 1995.

[37] R. L. Levine, D. Garland, C. N. Oliver et al., "Determination of carbonyl content in oxidatively modified proteins," Methods in Enzymology, vol. 186, pp. 464-478, 1990.

[38] M. Toraason, J. Clark, D. Dankovic et al., "Oxidative stress and DNA damage in Fischer rats following acute exposure to trichloroethylene or perchloroethylene," Toxicology, vol. 138, pp. 43-53, 1999.

[39] J. Cai, J. Yang, and D. P. Jones, "Mitochondrial control of apoptosis: the role of cytochrome c," Biochimica et Biophysica Acta, vol. 1366, no. 1-2, pp. 139-149, 1998.

[40] T. Nishikawa and E. Araki, "Impact of mitochondrial ROS production in the pathogenesis of diabetes mellitus and its complications," Antioxidants \& Redox Signaling, vol. 9, pp. 343-353, 2007.

[41] K. Green, M. D. Brand, and M. P. Murphy, "Prevention of mitochondrial oxidative damage as a therapeutic strategy in diabetes," Diabetes, vol. 53, no. 1, pp. S110-S118, 2004.

[42] Y. Y. Jang, J. H. Song, Y. K. Shin, E. S. Han, and C. S. Lee, "Protective effect of boldine on oxidative mitochondrial damage in streptozotocin-induced diabetic rats," Pharmacological Research, vol. 42, no. 4, pp. 361-371, 2000.

[43] L. Zhang, A. Zalewski, Y. Liu et al., "Diabetes-induced oxidative stress and low-grade inflammation in porcine coronary arteries," Circulation, vol. 108, no. 4, pp. 472-478, 2003.

[44] H.-C. Yen, T. D. Oberley, C. G. Gairola, L. I. Szweda, and D. K. St. Clair, "Manganese superoxide dismutase protects mitochondrial complex I against adriamycin-induced cardiomyopathy in transgenic mice," Archives of Biochemistry and Biophysics, vol. 362, no. 1, pp. 59-66, 1999.

[45] R. Kakkar, S. V. Mantha, J. Radhi, K. Prasad, and J. Kalra, "Increased oxidative stress in rat liver and pancreas during progression of streptozotocin-induced diabetes," Clinical Science, vol. 94, no. 6, pp. 623-632, 1998.

[46] T. Adachi, H. Ohta, K. Hirano, K. Hayashi, and S. L. Marklund, "Non-enzymic glycation of human extracellular superoxide dismutase," Biochemical Journal, vol. 279, no. 1, pp. 263-267, 1991.

[47] S. Salvioli, E. Sikora, E. L. Cooper, and C. Franceschi, "Curcumin in cell death processes: a challenge for CAM of age-related pathologies," Evidence-Based Complementary and Alternative Medicine, vol. 4, no. 2, pp. 181-190, 2007.

[48] D. L. Croteau, C. M. J. ap Rhys, E. K. Hudson, G. L. Dianov, R. G. Hansford, and V. A. Bohr, "An oxidative damagespecific endonuclease from rat liver mitochondria," Journal of Biological Chemistry, vol. 272, no. 43, pp. 27338-27344, 1997.

[49] F. Cabreiro, C. R. Picot, M. Perichon, J. Castel, B. Friguet, and I. Petropoulos, "Overexpression of mitochondrial methionine sulfoxide reductase B2 protects leukemia cells from oxidative stress-induced cell death and protein damage," Journal of Biological Chemistry, vol. 283, no. 24, pp. 16673-16681, 2008.

[50] K. Yao, P. P. Ye, L. Zhang, J. Tan, X. J. Tang, and Y. D. Zhang, "Epigallocatechin gallate protects against oxidative stress-induced mitochondria-dependent apoptosis in human lens epithelial cells," Molecular Vision, vol. 14, pp. 217-223, 2008.

[51] K. K. Singh, "Mitochondria damage checkpoint in apoptosis and genome stability," FEMS Yeast Research, vol. 5, no. 2, pp. 127-132, 2004.

[52] N. Morita, K. Iizuka, K. Okita et al., "Exposure to pressure stimulus enhances succinate dehydrogenase activity in L6 myoblasts," American Journal of Physiology, vol. 287, no. 6, pp. E1064-E1069, 2004. 
[53] K. Sakai, K. Matsumoto, T. Nishikawa et al., "Mitochondrial reactive oxygen species reduce insulin secretion by pancreatic $\beta$-cells," Biochemical and Biophysical Research Communications, vol. 300, no. 1, pp. 216-222, 2003. 


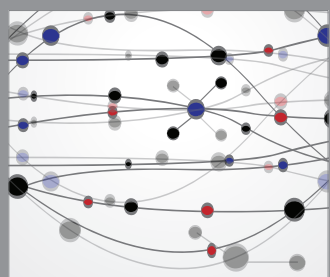

The Scientific World Journal
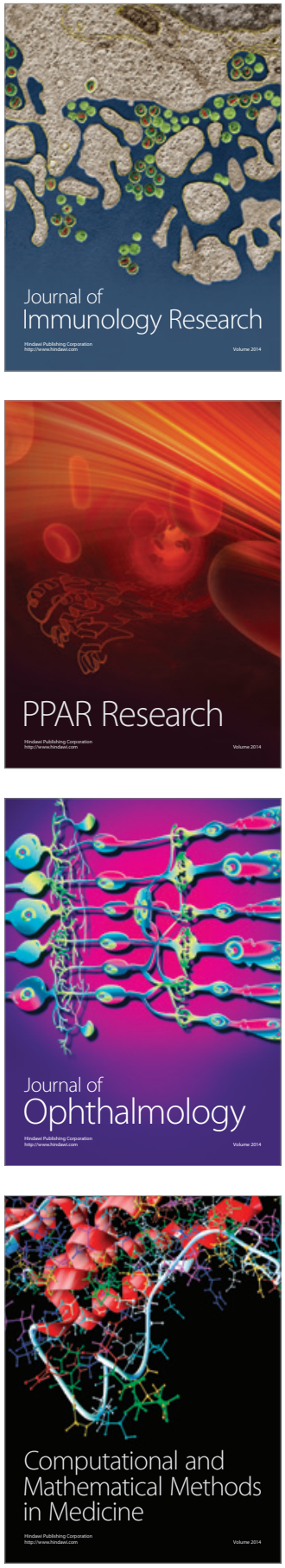

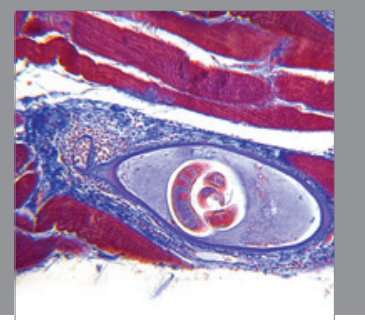

Gastroenterology

Research and Practice
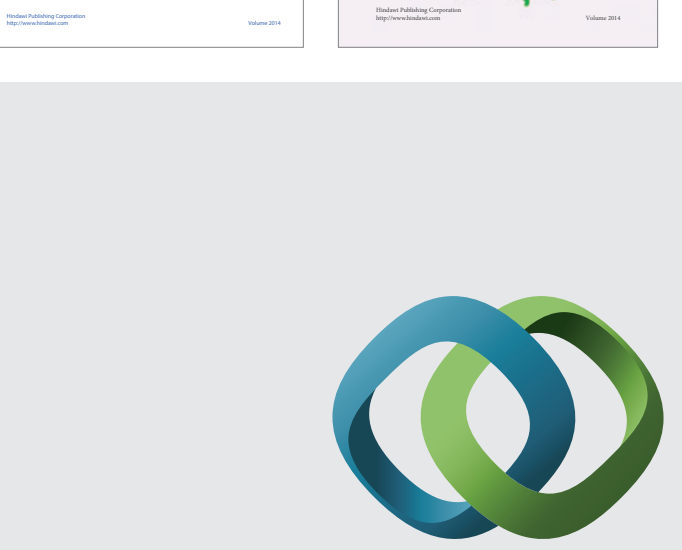

\section{Hindawi}

Submit your manuscripts at

http://www.hindawi.com
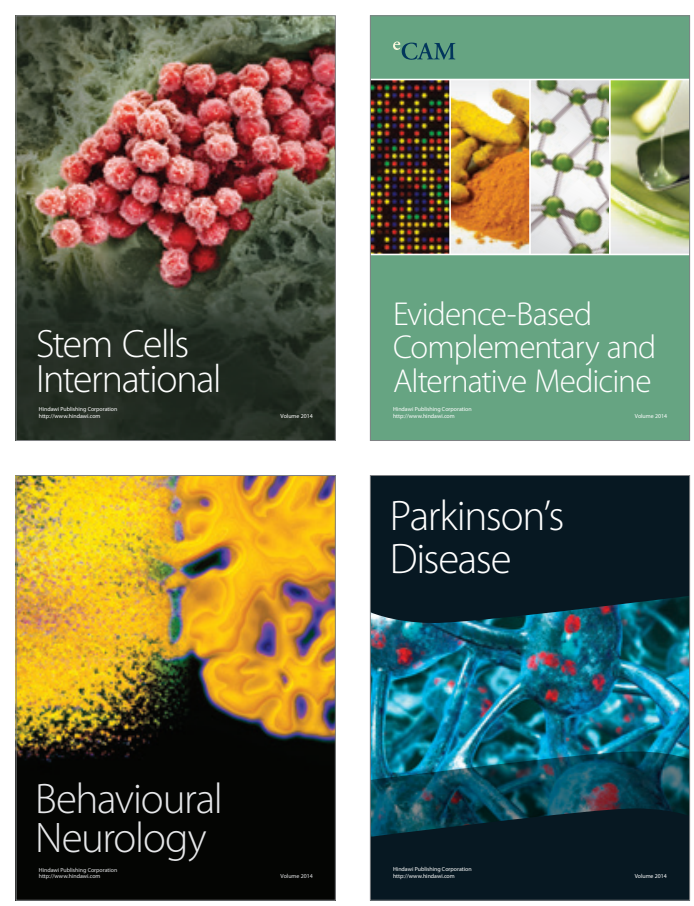

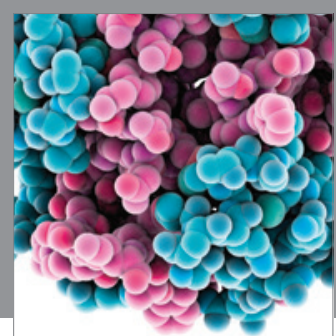

Journal of
Diabetes Research

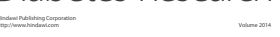

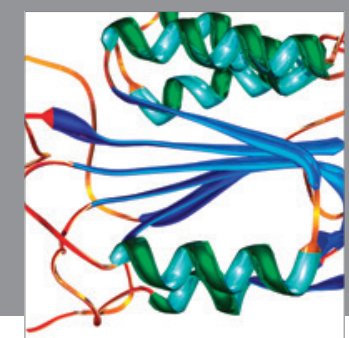

Disease Markers
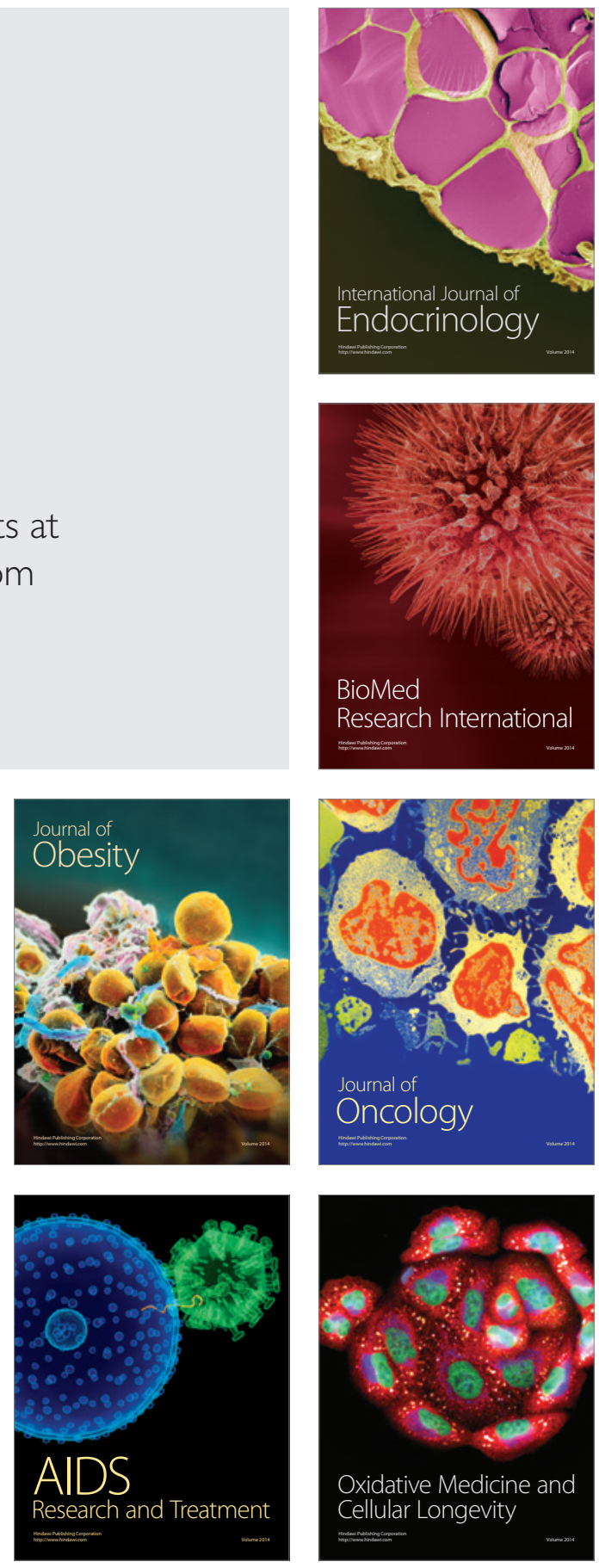